\title{
Research on Operation Benefit Evaluation of Power Network Project Based on Combination Weighting Method
}

\author{
Peng Dong ${ }^{1}$, Xue Yawei ${ }^{1}, L i$ Tianzhi $^{2}$, Wang Lina ${ }^{2}, L i$ Jinchao $^{2,3^{*}}$ \\ ${ }^{1}$ State Power Economic Research Institute China State Grid Corp, Beijing 102209, China \\ ${ }^{2}$ School of Economics and Management, North China Electric Power University, Beijing, 102206, China \\ ${ }^{3}$ Beijing Key Laboratory of New Energy and Low-Carbon Development, North China Electric Power University, Beijing, 102206, China
}

\begin{abstract}
Firstly, on the basis of economic efficiency, equipment and operational safety, public interest and other dimensions, this paper constructs an evaluation index system for operational benefit of power grid projects, and then a combined weighting method based on Analytic Network Process (ANP) and entropy weight method is established. Finally, an empirical study is carried out based on the actual data of power grid projects, and the research results prove the effectiveness of the model.
\end{abstract}

\section{Introduction}

The power grid is an important platform for power energy transmission. The construction of various types of power grid projects centering on the development of the power grid is to improve the transmission capacity, transmission quality, transmission efficiency, and other performance of the platform. Obviously, different types of projects have different development needs. At present, there have been some achievements in the research on the efficiency of power grid projects. For example, You Weiyang[1] put forward the efficiency and benefit evaluation algorithms of grid investment projects in different regions through rough set and approximate ideal solution method. Jiang Jianxun[2] comprehensively considered environmental economic benefits, social benefits and financial constraints, built a grid portfolio project model, and solved the model using genetic algorithms. Song Chang[3]believed that compared with financial evaluation, the economic benefit evaluation can reflect the social benefits generated by the grid construction project more intuitively and comprehensively. Therefore, benefit calculation model and power grid construction project examples are adopted to analyze the construction strategy of economic benefit post-evaluation system. Zhu Xinxin[4]introduced the whole life cycle cost theory, constructed the economic benefit post-evaluation index system applicable to the grid technical transformation project, and established a life-cycle cost-based theory. Yu Yuezhong[5] selected DEA as the measurement method of investment efficiency according to the characteristics of power grid project, and used entropy weight method to empower input and output indicators, and introduced the concept of "discrimination" on the basis of entropy weight method to screen the obtained input-output indicators.
Therefore, this paper firstly constructs the evaluation index system of grid project operation benefit, and then establishes a combined weighting evaluation method based on ANP and entropy weight method, and carries out empirical research based on the actual data of grid project.

\section{Construction of grid project operation benefit evaluation index system}

This paper establishes an evaluation index system for operational benefit of power grid projects. By consulting relevant experts and analyzing and summarizing expert opinions, objectively synthesizing most expert experience and subjective judgments, making reasonable estimates of a large number of factors that are difficult to use technical methods for quantitative analysis, after multiple rounds of consultation, feedback and adjustment, standardized indicator scores were established for each indicator in the project-level operational benefit evaluation index system. The indicators and criteria are shown in Table 1 below.

\section{Power grid project operation benefit evaluation method}

\subsection{Analytic Network Process (ANP) And Entropy Method}

The ANP method was proposed in 1996 on the basis of the AHP method. It is suitable for solving the problem of internal elements being independent. The basic implementation steps are as follows:

1) Establishment of index structure. According to the previous index system, we analyze the relevance between the indexes and set up the model of network

Corresponding author:274883292@qq.com 
hierarchy analysis. 2) Establishment of judgment matrix and sort vector. Generate pairwise comparisons to estimate the relative importance of various elements at each level. 3) Compare the internal and external relationships between the elements of other element sets, and then get the unweighted super matrix and weighted super matrix. Nevertheless, because of the complex calculation process, we employ the software of Super Decision for use to obtain the final weight.

The entropy method is a type of objective weighting method and indexes with relatively large degrees of change have a greater weight.

Data standardization. 2) Calculate the entropy value of each index. 3) Calculate index weight.

\subsection{Combination weighting method}

The weight vectors obtained by ANP and entropy weight method are $u$ and $v$ respectively. Their weight distribution coefficients are $\alpha$ and $\beta$, and $w$ is the combinatorial weight vector. Based on the idea of relative entropy, the mathematical model to solve the combinatorial weight is established:

$$
\left\{\begin{array}{c}
\min Q(\alpha, \beta)=\sum_{j=1}^{m} w_{j} \ln \left(w_{j} / u_{j}\right)+\sum_{j=1}^{m} w_{j} \ln \left(w_{j} / v_{j}\right) \\
\text { s.t. } \quad \alpha+\beta=1, \quad w_{j}=\alpha \cdot u_{j}+\beta \cdot v_{j}
\end{array}\right.
$$

Where, $0 \leq \alpha \leq 1, \quad 0 \leq \beta \leq 1, \quad \alpha+\beta=1, m$ is the number of the indexes, $Q(\alpha, \beta)$ is the relative entropy. According to the formula, it can get the combinatorial weight.

\section{Empirical research}

In this paper, the empirical study on the operational benefit of power grid projects is carried out by taking the wind power transmission project as an example. After the above calculation, $\alpha=0.55, \beta=0.45$. The corresponding combined weights and index scores are shown in the following Table 1.

The economic score was 2.4559 (full mark was 3.3620 , the proportion was $73.05 \%$ ), the safety score was 3.328 (full mark was 3.871, the proportion was $85.97 \%$ ), the social score was 0.769 (full mark was $1.293,77.92 \%$ ) and the environmental category score was 1.1532 points (full mark was $1.48,77.01 \%$ ). The total score of the project is 7.7061 points (out of 10 points), converted to a hundred-mark system, the total score of the project is 77.061 points. It can be seen from the above analysis that in the overall operational benefit evaluation of the project, the benefit scores are: safety $>$ economic $>$ environmental $>$ social, and the overall operational benefit is at a medium level.

Among the economic indicators, the internal income of the project has reached the financial project benchmark rate of $7 \%$, and its net present value is also greater than 0 , indicating that the project has better profitability. In terms of social benefits, since the construction of this project has an important impact on stabilizing the level of local social and economic development, it has not only economic significance, but also social significance. It can be seen from the environmental indicators that the project is lacking in energy conservation. Regarding vegetation damage, since the project is located in the developed area, only a small amount of vegetation is destroyed, and it can be restored as the project ends. Therefore, it is considered that there is no vegetation damage. The safety index data reflects the operation effect of the project. For example, the N-1 pass rate of this project reaches $100 \%$, which satisfies the "Guidelines for Safety and Stability of Power Systems". The number of power failures is 0 , indicating that the project has been maintained in a safe and reliable stable operation since it was put into operation

Table 1. The indicators and criteria

\begin{tabular}{|c|c|c|c|c|c|}
\hline Dimension & Index & Scoring criteria & $\begin{array}{l}\text { The } \\
\text { combined } \\
\text { weight }\end{array}$ & $\begin{array}{l}\text { Full } \\
\text { score }\end{array}$ & Score \\
\hline \multirow{5}{*}{$\begin{array}{l}\text { Economic } \\
\text { efficiency }\end{array}$} & $\begin{array}{l}\text { Added power per unit } \\
\text { investment (A1) }\end{array}$ & $\begin{array}{l}\text { Comparing with the similar functional } \\
\text { projects and giving the scoring coefficient } \\
{[0,1] . \text { The final score }=\text { full score } * \text { the }} \\
\text { scoring coefficient. }\end{array}$ & 0.0484 & 10 & 7 \\
\hline & $\begin{array}{l}\text { Added load per unit } \\
\text { investment(A2) }\end{array}$ & $\begin{array}{l}\text { The final score }=\text { full score } * \text { the scoring } \\
\text { coefficient. }\end{array}$ & 0.0428 & 10 & 6 \\
\hline & $\begin{array}{l}\text { Main business } \\
\text { revenue per unit } \\
\text { investment (A3) }\end{array}$ & $\begin{array}{l}\text { The final score }=\text { full score } * \text { the scoring } \\
\text { coefficient. }\end{array}$ & 0.0337 & 10 & 5 \\
\hline & $\begin{array}{l}\text { Net present value } \\
\text { (A4) }\end{array}$ & $\begin{array}{l}\text { When the index value is greater than or } \\
\text { equal to } 0 \text {, the score is } 10 . \text { Otherwise, the } \\
\text { score is } 0 \text {. }\end{array}$ & 0.0211 & 10 & 10 \\
\hline & $\begin{array}{l}\text { Transmission and } \\
\text { distribution costs per } \\
\text { unit power (A5) } \\
\end{array}$ & $\begin{array}{l}\text { The final score }=\text { full score } * \text { the scoring } \\
\text { coefficient. }\end{array}$ & 0.0287 & 10 & 6 \\
\hline $\begin{array}{l}\text { Utilization } \\
\text { efficiency }\end{array}$ & Line loss rate (A6) & $\begin{array}{l}\text { The final score }=(1 \text {-actual value of index }) \\
* 10 \text {. }\end{array}$ & 0.0480 & 10 & 9.399 \\
\hline
\end{tabular}




\begin{tabular}{|c|c|c|c|c|c|}
\hline \multirow[t]{6}{*}{ Dimension } & Index & Scoring criteria & $\begin{array}{l}\text { The } \\
\text { combined } \\
\text { weight }\end{array}$ & $\begin{array}{l}\text { Full } \\
\text { score }\end{array}$ & Score \\
\hline & $\begin{array}{l}\text { Internal rate of return } \\
\text { (IRR) (A7) }\end{array}$ & $\begin{array}{l}\text { If the index value is } \geq 8 \% \text {, the score is } 10 \text {; if } \\
7 \% \leq \text { the index value }<8 \% \text {, the score is } 8 \text {; if } \\
6 \% \leq \text { the index value }<7 \% \text {, the score is } 6 \text {; if } 0 \\
<\text { the index value }<6 \% \text {, the score is } 4 \text {; or the } \\
\text { score is } 0 \text {. }\end{array}$ & 0.0365 & 10 & 8 \\
\hline & $\begin{array}{l}\text { Standby ratio of } \\
\text { transformer in } \\
\text { operation }(\mathrm{A} 8) \\
\end{array}$ & $\begin{array}{l}\text { The final score }=\text { full score } * \text { the scoring } \\
\text { coefficient. }\end{array}$ & 0.0251 & 10 & 10 \\
\hline & Load rate (A9) & $\begin{array}{l}\text { If the index value is } \geq 90 \% \text {, the score is } 10 \text {. } \\
\text { If the index value is less than } 90 \% \text {, for every } \\
0.01 \% \text { decrease, the score will be } 1 \% \\
\text { deducted. }\end{array}$ & 0.0188 & 10 & 10 \\
\hline & $\begin{array}{l}\text { Average load rate of } \\
\text { transformer or line } \\
\text { (A10) }\end{array}$ & $\begin{array}{l}\text { If the index value is between } 20 \% \text { to } 50 \% \text {, } \\
\text { the score is } 10 \text {. If the index value is in } \\
{[10 \%, 20 \%) \cup(50 \%, 60 \%] \text {, the score is }} \\
6 \text {. If the index value is }<10 \% \text { or }>60 \% \text {, the } \\
\text { score is } 2 \text {. }\end{array}$ & 0.0235 & 10 & 2 \\
\hline & $\begin{array}{l}\text { Ratio of double } \\
\text { (multiple) circuit } \\
\text { with same tower } \\
\text { (A11) }\end{array}$ & The final score $=$ full score $*$ the index value. & 0.0096 & 10 & 8.276 \\
\hline \multirow{4}{*}{$\begin{array}{l}\text { Equipment } \\
\text { security }\end{array}$} & $\begin{array}{l}\text { Line overload rate } \\
\text { (A12) }\end{array}$ & $\begin{array}{l}\text { The final score }=\text { full score } * \text { (1-the index } \\
\text { value). }\end{array}$ & 0.0689 & 10 & 10 \\
\hline & $\begin{array}{l}\text { Proportion of GIS } \\
\text { equipment (A13) }\end{array}$ & The final score $=$ full score $*$ the index value. & 0.0229 & 10 & 0.36 \\
\hline & $\begin{array}{c}\text { Insulation rate of } \\
\text { overhead line(A14) }\end{array}$ & The final score $=$ full score $*$ the index value. & 0.0184 & 10 & 8.425 \\
\hline & $\begin{array}{l}\text { Proportion of } \\
\text { intelligent and } \\
\text { disaster prevention } \\
\text { equipment (A15) }\end{array}$ & The final score $=$ full score $*$ the index value. & 0.0323 & 10 & 0.92 \\
\hline \multirow{4}{*}{$\begin{array}{l}\text { Operation } \\
\text { security }\end{array}$} & $\begin{array}{l}\text { Number of power } \\
\text { failures (A16) }\end{array}$ & $\begin{array}{l}\text { If the index value is } 2 \text {, the score is } 8 \text {. For } \\
\text { each decrease of index value, } 10 \% \text { scores } \\
\text { will be added; for each increase of index } \\
\text { value, } 10 \% \text { scores will be deducted, the } \\
\text { upper limit of the score is } 10 .\end{array}$ & 0.0415 & 10 & 10 \\
\hline & Circuit trip rate (A17) & $\begin{array}{l}\text { The final score }=\text { full score } *(1-\text { the index } \\
\text { value). }\end{array}$ & 0.0732 & 10 & 10 \\
\hline & $\begin{array}{l}\text { Unplanned outage } \\
\text { rate of transformer } \\
\text { (A18) }\end{array}$ & $\begin{array}{l}110 \mathrm{kV} \text { and above: The basic criteria is } 0.171 \\
\text { times/ per hundred units per year, the target } \\
\text { criteria is } 0.052 \text { times/ per hundred units per } \\
\text { year, the average criteria is } 0.112 \text { times/ per } \\
\text { hundred units per year. If the index value } \\
\leq 0.052 \text {, the score is } 10 \text {. If } 0.052<\text { the index } \\
\text { value }<0.112 \text {, the score is } 9 \text {. If } 0.112 \leq \text { the } \\
\text { index value }<0.171 \text {, the score is } 8.5 \text {. If the } \\
\text { index value }=0.171 \text {, the score is } 8 \text {. If the } \\
\text { index value }>0.171 \text {, for each } 0.01 \% \text { decrease } \\
\text { of index value, } 1 \% \text { scores will be deducted. }\end{array}$ & 0.0609 & 10 & 10 \\
\hline & N-1 pass rate (A19) & $\begin{array}{l}\text { If the index value is } 100 \% \text {, the score is } 10 . \\
\text { For each } 0.01 \% \text { decrease, } 1 \% \text { scores will be } \\
\text { deducted. }\end{array}$ & 0.0690 & 10 & 10 \\
\hline \multirow[b]{2}{*}{$\begin{array}{l}\text { The public } \\
\text { interest }\end{array}$} & $\begin{array}{l}\text { New employment } \\
\text { (A20) }\end{array}$ & $\begin{array}{l}\text { The final score }=\text { full score } * \text { the proportion } \\
\text { of new employment in the total employment. }\end{array}$ & 0.0630 & 10 & 3 \\
\hline & $\begin{array}{l}\text { Public satisfaction } \\
\text { index (PSI) (A21) }\end{array}$ & $\begin{array}{l}\text { There are five grades: very good, good, } \\
\text { medium, bad, very bad, with the scores of } \\
10,8,5,3,1 \text {. Get the public evaluation by } \\
\text { questionnaire survey, and the final score is } \\
\text { the mean of all evaluation scores. }\end{array}$ & 0.0166 & 10 & 5 \\
\hline $\begin{array}{l}\text { Regional } \\
\text { economy }\end{array}$ & $\begin{array}{l}\text { Elastic coefficient of } \\
\text { the power } \\
\text { contribution (A22) }\end{array}$ & $\begin{array}{l}\text { The final score }=\text { full score } * \text { the scoring } \\
\text { coefficient. }\end{array}$ & 0.0311 & 10 & 10 \\
\hline
\end{tabular}




\begin{tabular}{|c|c|c|c|c|c|}
\hline \multirow[t]{2}{*}{ Dimension } & Index & Scoring criteria & $\begin{array}{c}\text { The } \\
\text { combined } \\
\text { weight }\end{array}$ & $\begin{array}{l}\text { Full } \\
\text { score }\end{array}$ & Score \\
\hline & $\begin{array}{l}\text { GDP per unit } \\
\text { power(A23) }\end{array}$ & $\begin{array}{l}\text { The final score }=\text { full score } * \text { the scoring } \\
\text { coefficient. }\end{array}$ & 0.0186 & 10 & 10 \\
\hline \multirow{2}{*}{$\begin{array}{l}\text { Energy-saving } \\
\text { and } \\
\text { environmental } \\
\text { protection }\end{array}$} & $\begin{array}{l}\text { Carbon dioxide } \\
\text { emissions (A24) }\end{array}$ & $\begin{array}{l}\text { The final score }=\text { full score } * \text { the scoring } \\
\text { coefficient. }\end{array}$ & 0.0385 & 10 & 8 \\
\hline & $\begin{array}{l}\text { Sulfur dioxide } \\
\text { emissions (A25) }\end{array}$ & $\begin{array}{l}\text { The final score }=\text { full score } * \text { the scoring } \\
\text { coefficient. }\end{array}$ & 0.0264 & 10 & 8 \\
\hline \multirow{2}{*}{$\begin{array}{l}\text { Environment } \\
\text { quality }\end{array}$} & $\begin{array}{c}\text { Environmental } \\
\text { acceptance rate after } \\
\text { completion (A26) }\end{array}$ & $\begin{array}{l}\text { The basic criteria is } 100 \% \text {, if the index value } \\
\text { is } 100 \% \text {, the score is } 10 \text {, or the score is } 0 \text {. }\end{array}$ & 0.0190 & 10 & 10 \\
\hline & $\begin{array}{c}\text { Vegetation } \\
\text { destruction rate } \\
\text { (A27) }\end{array}$ & $\begin{array}{l}\text { The final score }=\text { full score } * \text { the scoring } \\
\text { coefficient. }\end{array}$ & 0.0641 & 10 & 10 \\
\hline
\end{tabular}

\section{Conclusion}

Based on multiple dimensions, this paper constructs a grid project operational benefit evaluation index system, and then establishes a linear combination weighting method based on ANP and entropy weight method. Finally, taking the wind power transmission project as an example, the empirical research results prove the validity of the model.

This work has been supported by the Science and Technology Project of SGCC "Research on lean investment optimization method based on benefit analysis of the whole process of power grid".

\section{References}

1. W.Y. You, X.N. Wang, Electric Power Science and Engineering, Evaluation of Efficiency and Efficiency of Power Grid Investment Projects under the Supervision of Transmission and Distribution Price, 34, 6(2018)

2. J.X. Jiang, Y. Yuan, Industrial Technology and Economy, Research on portfolio optimization of power grid projects considering environmental benefits, 37 6(2018)

3. C. Song, L.Z. Cui, L.L. Fang, Communication World, Discussion on the construction of post-evaluation system for economic benefits of power grid construction projects, 2(2017)

4. X.X. Zhu, J.L. Zhu, Journal of Electric Power, Research on post-evaluation of economic benefits of power grid technical transformation project, 32 9(2017)

5. Y.Z. Yu, W. Zhang, X.W. Shen, Shaanxi Electric Power, Study on investment efficiency of power grid construction project based on entropy weight method-DEA model, 44 6(2016) 